\title{
Conodonts across the Devonian/Carboniferous boundary in SE Sardinia (Italy)
}

\author{
Angelo Mossoni, Nicola Carta, CARlo Corradini \& Claudia Spalletta
}

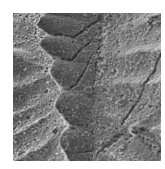

\begin{abstract}
The Bruncu Bullai section, located in SE Sardinia, exposes limestones from the styriacus Zone (upper Famennian) to the Upper duplicata Zone (Tournaisian), but the Upper praesulcata Zone is not documented; at the Devonian/Carboniferous boundary a black shales level, equivalent to the Hangenberg Shales, is present. Fifty-six conodont taxa were recovered, three of which are here described as new species: Polygnathus bicristatus, Po. nuragicus, Pseudopolygnathus granulobatus; two more species, probably new, are described, but left in open nomenclature because of the low number of specimens collected. The relative high abundance of Protognathodus and low abundance of Siphonodella in some levels and the opposite in others is discussed, and a new hypothesis on the occurrences of protognathodids as influenced by ecological factors is suggested. The early phase of the Hangenberg crisis is testified by a faunal turnover in an impoverished fauna within the deposition of limestones of the Lower praesulcata Zone. - Key words: conodonts, biostratigraphy, Devonian, Carboniferous, Devonian/Carboniferous boundary, Sardinia.
\end{abstract}

\begin{abstract}
Mossoni, A., Carta, N., Corradini, C. \& Spalletta, C. 2015. Conodonts across the Devonian/Carboniferous boundary in SE Sardinia (Italy). Bulletin of Geosciences 90(2), 371-388 (7 figures, 1 table). Czech Geological Survey, Prague. ISSN 1214-1119. Manuscript received June 12, 2014; accepted in revised form November 28, 2014; published online February 19, 2015; issued March 23, 2015.
\end{abstract}

Angelo Mossoni, Nicola Carta \& Carlo Corradini (corresponding author), Dipartimento di Scienze Chimiche e Geologiche, Università di Cagliari, via Trentino 51, I-09129 Cagliari, Italy; ang.mossonil@studenti.unica.it, nicola.carta1@virgilio.it, corradin@unica.it • Claudia Spalletta, Dipartimento di Scienze Biologiche, Geologiche e Ambientali, Alma Mater Studiorum Università di Bologna, via Zamboni 67, I-40126 Bologna, Italy; claudia.spalletta@unibo.it

The Devonian/Carboniferous boundary is defined by the first occurrence of the conodont Siphonodella sulcata; the GSSP is located in the La Serre Trench E', in Montagne Noire, southern France. However, problems both with the type section and the index taxon have been recently evidenced (see below for details), and researches on the Late Devonian and Early Carboniferous received new interest all around the world.

Up to now rocks across the Devonian/Carboniferous boundary in Sardinia have been documented only in the Monte Taccu section (Corradini et al. 2003, Mossoni et al. 2013). In this paper we present the conodont stratigraphy of the Bruncu Bullai section, located a few $\mathrm{km}$ east of Villasalto (Fig. 1), where a dozen of meters of Famennian and Tournaisian limestones are exposed. The Hangenberg equivalent Shales are represented by a few centimeters of black shales, dividing the Famennian from the Tournaisian limestones.

Up to now the occurrence of Lower Carboniferous rocks in Sardinia has been claimed by Olivieri (1970) near Villasalto, and proved in the Monte Taccu section, a few km west, by Barca et al. (2000), Corradini et al. (2003) and
Mossoni et al. (2013). In this paper new data on Upper Devonian and Lower Carboniferous conodonts in Sardinia are presented and a special attention is given to the relative abundance of Protognathodus and Siphonodella across the Devonian/Carboniferous boundary.

\section{The Devonian/Carboniferous boundary: an open problem}

The base of the Carboniferous System is defined by the first occurrence of the conodont species Siphonodella sulcata, within the claimed $S$. praesulcata-S. sulcata lineage, and the GSSP is located at the La Serre Trench E' section, Montagne Noire, France (Paproth et al. 1991). Flajs \& Feist (1988) published a biometric study of S. praesulcata and S. sulcata based on the La Serre faunas, demonstrating that transitional forms are very common. The FAD of $S$. sulcata was chosen to define the base of the Tournaisian, but difficulties in discriminating S. praesulcata from S. sulcata arose immediately (e.g., Wang \& Yin 1984, Ji 1987, Flajs $\&$ Feist 1988). Further studies on the stratotype section 


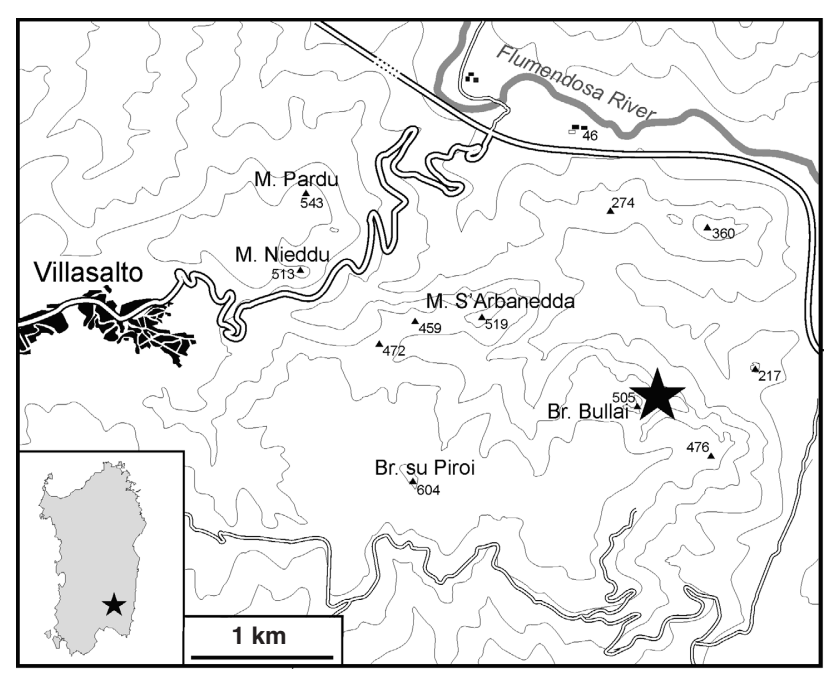

Figure 1. Location map of the Bruncu Bullai section.

have revealed a series of problems, such as lack of other important stratigraphic guides and the existence of reworking (e.g., Flajs \& Feist 1988, Ziegler \& Sandberg 1996, Casier et al. 2002, Kaiser 2009).

A redefinition of the Devonian/Carboniferous boundary was reputed necessary, and in 2008 the International Commission on Stratigraphy established a working group with the goal to propose a new criterion for defining the boundary and finding a new GSSP. In this scenario, all conodont genera of the latest Devonian and earliest Carboniferous are restudied in order to exploit their potential for biostratigraphy across the Devonian/Carboniferous boundary (Corradini et al. 2013) and taxonomic revisions of selected taxa are in progress (i.e. early siphonodellids, Kaiser \& Corradini 2011; protognathodids, Corradini et al. 2011). Several sections are under investigation around the world, both restudying already known localities (i.e. Mossoni et al. 2013, Kumpan et al. 2014) and exploiting new ones (i.e. Bahrami et al. 2011, Becker et al. 2013, Girard et al. 2014, Kumpan et al. 2014, Kalvoda et al. 2015).

\section{Geological setting}

In Sardinia an almost complete portion of the southern branch of the Variscan orogenic belt crops out. It is characterized by non-metamorphosed to high-grade rocks of Early Cambrian to Early Carboniferous age involved in a complex polyphase deformation. The main result of the Variscan orogeny in Sardinia is a tectono-metamorphic partition with, from north to south: an Inner Zone, with medium to high grade metamorphism, thrusted over a Nappe Zone, with green schist metamorphism that overthrusted a Foreland Zone affected by very low grade regional metamorphism (Funedda \& Oggiano 2009, and references therein).
The studied area is located in the External Nappe Zone, and belongs to the Gerrei tectonic unit, where the most complete mid-Palaeozoic sequence of the whole island is preserved. The metamorphic grade is very low (green schist facies) and allows good biostratigraphic investigation. The sequence of the Gerrei tectonic unit starts with a thick pile of sandstones ("Arenarie di San Vito") of Mid Cambrian-Early Ordovician age, followed by a huge amount of Middle Ordovician volcanic rocks. The Upper Ordovician is mainly represented by terrigenous littoral sediments with basaltic intercalations, and silicified limestones at the top. The Silurian and lowermost Devonian exposes black shales and limestones in the classical Thuringian facies triad (Jaeger 1976): Lower Graptolitic Shales, Ockerkalk, and Upper Graptolitic Shales. This unit grades into an alternation of dark pelites and nodular marly limestone ("Tentaculitic shales and limestones") of Early-Middle Devonian age. The calcareous content progressively increases and the Upper Devonian-lowermost Carboniferous sediments are represented by massive limestones known as "Clymeniae limestones" (see below). Above, several dozens of meters of metasandstones and metaconglomerates ("Conglomerato di Villasalto", Auct.) are present. They represent the transition to the terrigenous sedimentation terminating the pelagic sequence of the Palaeozoic in SE Sardinia. For a complete description of the Gerrei tectonic unit refer to Corradini et al. (2002) and Corradini \& Ferretti (2009).

\section{The "Clymeniae limestones" of Sardinia}

The Upper Devonian-Lower Carboniferous limestones consist mainly of grey massive limestones, known as "Clymeniae limestones" because of the occurrence of ammonoids in some levels (Lovisato 1894, Corradini 2007). The apparent thickness of this unit may reach hundreds of meters, but tectonic repetitions of the sequence are highly probable (Carmignani et al. 1986); the real thickness is more likely about 50-70 m (Corradini 2008). Apart from a few crinoid stems, ammonoids concentrated in a few levels, mainly across the annulata and Dasberg events, are the only abundant macrofossils. The microfacies is a poorly fossiliferous micrite with scarce fossil remains in the ammonoid-bearing beds: ostracodes, small shells (bivalves or brachiopods), fragments of echinoderms, gastropods, and rare trilobites. Conodonts are abundant; fish teeth and very rare brachiopods have been reported from acid-insoluble residues (Corradini 1998a, 1998c; Corradini et al. 2003; Derycke et al. 2008; Mossoni et al. 2013). Biofacies and microfacies suggest a pelagic environment for these limestones. The Clymeniae limestones have been biostratigraphically investigated on the basis of conodonts by several authors in the last fifty years (Pomesano Cherchi 

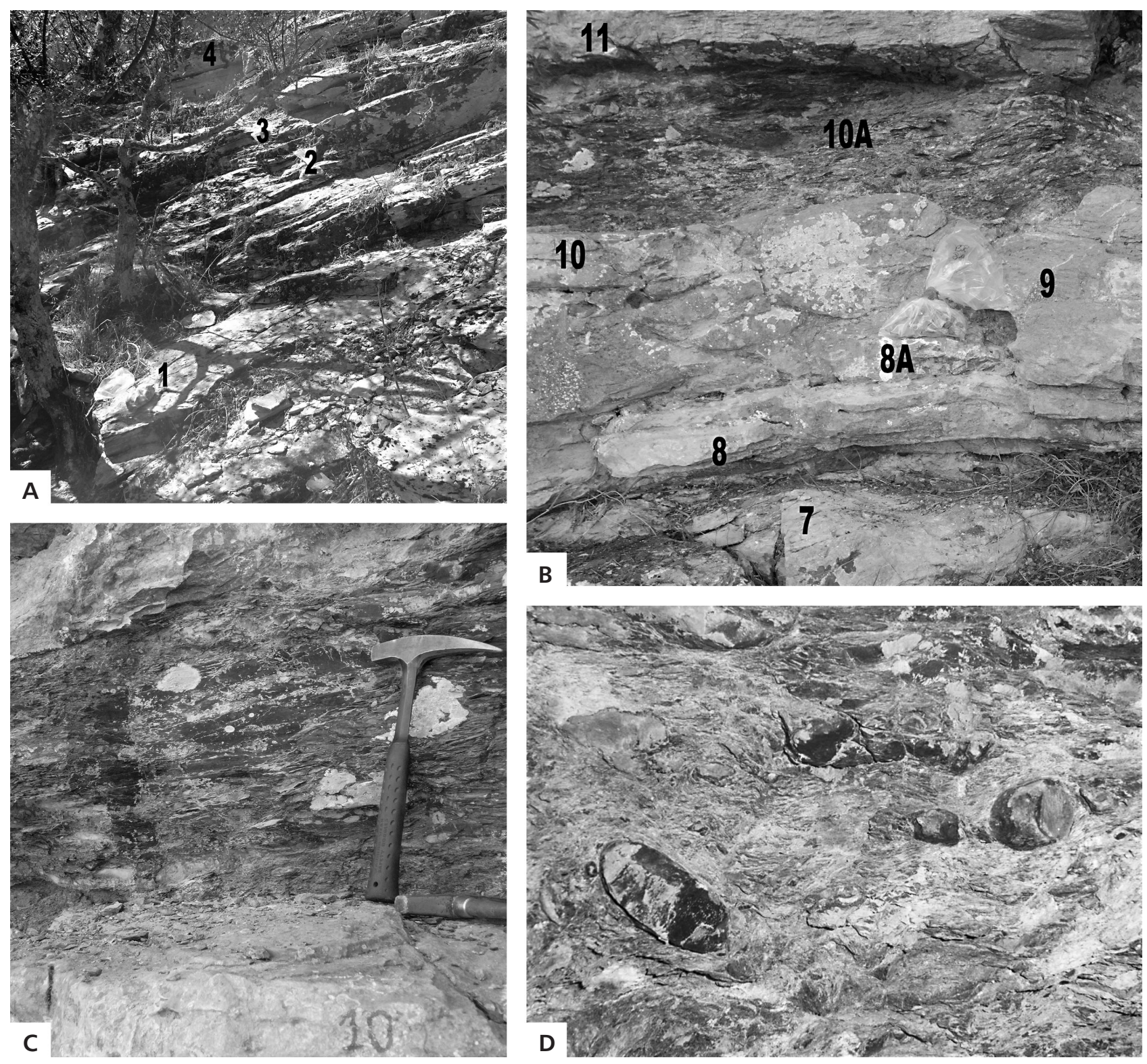

Figure 2. Selected views of the studied section. $\bullet A-$ general view of the lower part of the Bruncu Bullai section. $\bullet$ B - view of the upper part of the section. - $\mathrm{C}$-detail of the black shale level between samples BTE 10,11 . D - close-up view of nodules in the lower part of the shale level between samples BTE $10,11$.

1963; Olivieri 1965, 1970, 1985; Murru 1975; Spalletta \& Vai 1982; Barca \& Spalletta 1985; Barca et al. 1986; Corradini 1998a, 1998b, 1998c, 1998d, 2002, 2003, 2008; Corradini et al. 2001, 2003; Mossoni et al. 2013), providing a late Frasnian (Upper hassi Zone)-early Tournaisian (Upper duplicata Zone) age for this unit.

\section{The Bruncu Bullai section}

The Bruncu Bullai (BTE) section is located few $\mathrm{km} \mathrm{SW}$ of Villasalto in the northern slope of Bruncu Bullai hill at coordinates: $39^{\circ} 29^{\prime} 13.42^{\prime \prime} \mathrm{N}$; 9 $9^{\circ} 26^{\prime} 15.25^{\prime \prime} \mathrm{E}$ (Fig. 1).
The section exposes about eleven meters of massive grey limestone arranged in beds with a thickness from $20 \mathrm{~cm}$ up to $2 \mathrm{~m}$ (Fig. 2C). A few limestone beds are present below the base of the section, but have not been sampled because they are highly tectonized.

Two levels of black shales are present in the upper part of the section. The first level, between samples BTE 7 and BTE 8 is only a few centimeters thick and has a limited calcareous component. The second shaley level (between samples BTE 10 and BTE 11) is about $50 \mathrm{~cm}$ thick, with evident small lateral variations, and includes in its lower part a few chert nodules and a thin discontinuous calcareous level. A thrust, or a fault, follows this black shale level, 
evidenced in the field by a minor unconformity. Above thick beds of limestones are present.

According to conodont data (see below), the first shale level lies at or just below the Devonian/Carboniferous boundary, and can be considered as an equivalent of the Hangenberg Shales, whereas no data have been obtained from the second shale. However, according to its stratigraphical position it is likely Tournaisian in age and may represent a deeper sedimentation episode within the early phases of the Variscan orogeny. Analogous sediments represented by shales and cherts, some with limestone lenses, are documented in several other regions (i.e. Carnic Alps, Schönlaub 1969; Montagne Noire, Kaiser et al. 2009; Rhenisches Schiefergebirge, Korn \& Weyer 2003; Poland, Dzik 1997; Morocco, Korn 1999). These strata have been dated to the Lower crenulata Zone and testify a global transgression and a faunal turnover named "Lower Alum Shale Event" by Becker (1993).

The microfacies is a mudstone-wackestone. Some fossil remains, mainly brachiopods and ammonoids, have been observed in thin section (Fig. 5). Bioclasts, mainly fragments of goniatites, are readily recognizable despite the faint metamorphic imprint; they are more frequent in the uppermost levels. The upper part of the section (samples 7-10A) shows the effect of tectonism with evident calcite recrystallization, stylolite and tension gashes structures (Fig. 5D).

\section{Conodont data}

Fifteen samples, weighting 0.4 to $3.7 \mathrm{~kg}$, have been collected from the Bruncu Bullai section, for a total amount of about $30 \mathrm{~kg}$ of limestone (Table 1). The samples were dissolved with conventional formic acid technique. All the samples, but BTE 10A were productive, yielding more than 2,500 conodonts (Table 1). The state of preservation is quite good, even if some specimens are broken or tectonically deformed. These deformed elements are present in all samples, while are especially abundant in samples BTE 1 and BTE 11.

The abundance is variable (Fig. 4), from a minimum of 9.7 conodonts $/ \mathrm{kg}$ in sample BTE $6 \mathrm{C}$ to a maximum of 270 conodonts $/ \mathrm{kg}$ in sample BTE 9; the average of 88.7 conodont $/ \mathrm{kg}$ is similar to the other sections studied in the Clymeniae limestones of Sardinia.

Conodonts color is black (CAI $=5-5.5)$, as in all other sections in the Upper Devonian of Sardinia.

Fifty-seven taxa, between species and subspecies, belonging to the genera Branmehla, Bispathodus, Icriodus, Mehlina, Palmatolepis, Polygnathus, Protognathodus, Pseudopolygnathus, and Siphonodella have been recognized (Fig. 3).

Palmatolepis is the dominant genus in the lower part of the section (samples BTE 1-2), up to the lower part of the
Lower expansa Zone, when Bispathodus starts to be very abundant (Fig. 4). Bispathodus continues to be very abundant, and together with Branmehla, represents the majority of the association of the Upper expansa Zone (sample BTE 6-6B). Within the Lower praesulcata Zone (sample BTE 6C), Polygnathus became the dominant genus. In the Carboniferous part of the section Polygnathus constitutes up to $80 \%$ of the assemblages. In sample BTE 9 (Lower duplicata Zone) Polygnathus tenuiserratus represents more than one quarter of the fauna.

\section{Biostratigraphy}

The conodont zonation used in this paper is the scheme proposed for Sardinia by Corradini (2008), that is a rielaboration of the Late Devonian Standard Conodont Zonation (Ziegler \& Sandberg, 1990) and the Late Devonian-Early Carboniferous Zonation of Sandberg et al. (1978). An alternative zonation across the Devonian/Carboniferous boundary has been proposed by Kaiser et al. (2009), who replaced the Middle and Upper praesulcata zones by Ziegler \& Sandberg (1990) with a "costatus-kockeli interregnum" (CKI) and a Pr. kockeli Zone, respectively, and applied a proposal by Ji (1985) for the duplicata-sandbergi interval.

The Lower marginifera Zone. - The Lower marginifera Zone is discriminated in the uppermost part of the section, above the tectonic duplication by the occurrence of the marker Palmatolepis marginifera marginifera in sample BTE 12. The association is dominated by Palmatolepis.

The styriacus Zone. - The styriacus Zone corresponds to an undifferentiated postera Zone of Ziegler \& Sandberg (1990). It has been discriminated at the base of the section (sample BTE 1) by the presence of the marker, Polygnathus styriacus. Palmatolepis gr. gracilis and Pa. perlobata schindewolfi are the most abundant taxa.

A high number of ramiform elements was recovered from this level, representing about one half of the findings, although the state of preservation is quite poor.

The Lower expansa Zone. - The Lower expansa Zone (samples 2-3) is recognized by the first occurrence of the marker, Palmatolepis gracilis expansa. Palmatolepis perlobata postera is here reported for the first time in Sardinia from this interval. This late entry of $\mathrm{Pa}$. perlobata postera also occurs in the Carnic Alps (Perri \& Spalletta 1998). Pseudopolygnathus dissimilis and Branmehla werneri are exclusive of this zone, whereas Bispathodus jugosus has its first occurrence. Palmatolepis gracilis gracilis is the most abundant species of this zone.

The Middle expansa Zone. - The Middle expansa Zone 
Angelo Mossoni et al. • Conodonts across the Devonian/Carboniferous boundary in SE Sardinia

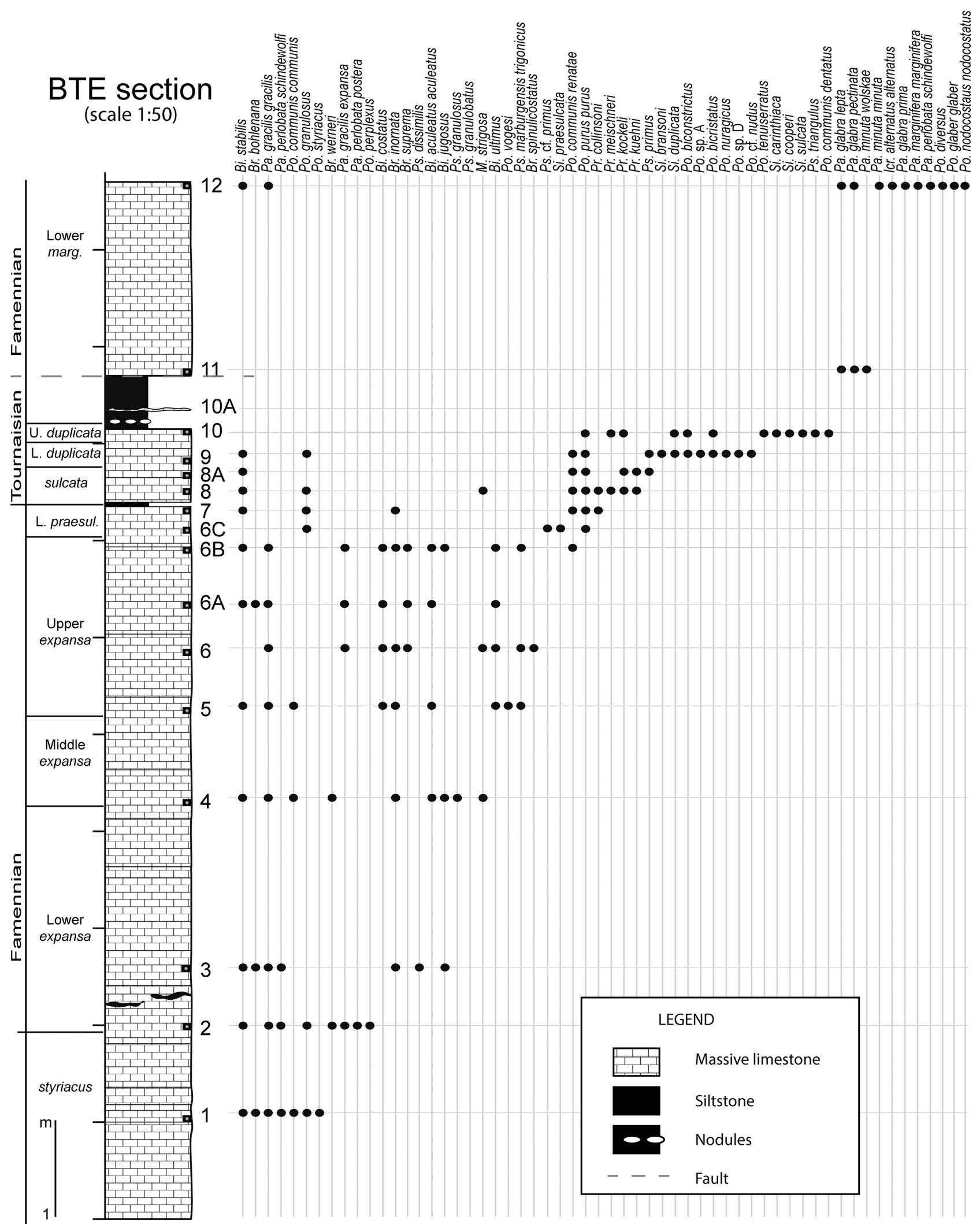

Figure 3. Stratigraphic log, biozonation and conodont occurrence of the Bruncu Bullai section. Abbreviation: Bi. - Bispathodus, Br. - Branmehla, Icr. - Icriodus, M. - Mehlina, Pa. - Palmatolepis, Ps. - Pseudopolygnathus, Pr. - Protognathodus, Po. - Polygnathus, Si. - Siphonodella. 
Table 1. Distribution of conodonts in the Bruncu Bullai section. P. - Polygnathus; Ps. - Pseudopolygnathus

\begin{tabular}{|c|c|c|c|c|c|c|c|c|c|c|c|c|c|c|c|c|c|c|}
\hline \multirow[b]{3}{*}{ Species } & \multicolumn{10}{|c|}{ Famennian } & \multicolumn{4}{|c|}{ Tournaisian } & \multirow{3}{*}{$\frac{\sigma .}{10 \mathrm{~A}}$} & \multicolumn{2}{|c|}{ Famennian } & \multirow{3}{*}{ Total } \\
\hline & \multirow{2}{*}{ 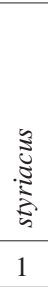 } & \multicolumn{2}{|c|}{ 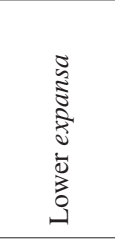 } & \multirow[t]{2}{*}{ 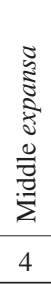 } & \multicolumn{4}{|c|}{ 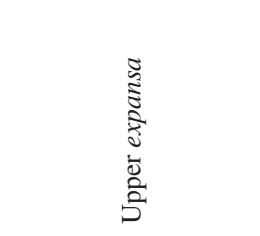 } & \multicolumn{2}{|c|}{ 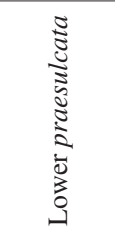 } & \multicolumn{2}{|c|}{$\frac{\mathbb{\Xi}}{\stackrel{\Xi}{\Xi}}$} & \multirow[t]{2}{*}{ 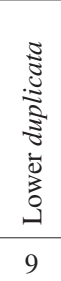 } & \multirow[t]{2}{*}{ 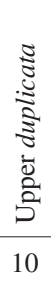 } & & \multirow[t]{2}{*}{\begin{tabular}{|c|} 
\\
\\
\\
11
\end{tabular}} & \multirow[t]{2}{*}{ 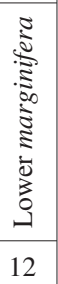 } & \\
\hline & & 2 & 3 & & 5 & 6 & $6 \mathrm{~A}$ & $6 \mathrm{~B}$ & $6 \mathrm{C}$ & 7 & 8 & $8 \mathrm{~A}$ & & & & & & \\
\hline Bispathodus aculeatus aculeatus & & & & 5 & 18 & & 15 & 23 & & & & & & & & & & 61 \\
\hline Bispathodus costatus & & & 1 & & 51 & 40 & 19 & 38 & & & & & & & & & & 149 \\
\hline Bispathodus jugosus & & & & 1 & & & & 3 & & & & & & & & & & 4 \\
\hline Bispathodus spinulicostatus & & & & & & 16 & & & & & & & & & & & & 16 \\
\hline Bispathodus stabilis & 3 & 36 & 8 & 4 & 6 & & 2 & 14 & & 6 & 15 & 11 & 12 & & & & 1 & 118 \\
\hline Bispathodus ultimus & & & & & 49 & 27 & 7 & 18 & & & & & & & & & & 101 \\
\hline Branmehla bohlenana & 1 & & 4 & & & & 1 & & & & & & & & & & & 6 \\
\hline Branmehla inornata & & & 9 & 5 & 6 & 25 & & 7 & & 1 & & & & & & & & 53 \\
\hline Branmehla suprema & & & & & & 79 & 18 & 15 & & & & & & & & & & 112 \\
\hline Branmehla werneri & & 3 & & & & & & & & & & & & & & & & 3 \\
\hline Icriodus alternatus alternatus & & & & & & & & & & & & & & & & & 1 & 1 \\
\hline Mehlina strigosa & & & & 5 & & 2 & & & & & 5 & & & & & & & 12 \\
\hline Palmatolepis glabra lepta & & & & & & & & & & & & & & & & 2 & 4 & 6 \\
\hline Palmatolepis glabra pectinata & & & & & & & & & & & & & & & & 2 & 17 & 19 \\
\hline Palmatolepis glabra prima & & & & & & & & & & & & & & & & & 14 & 14 \\
\hline Palmatolepis gracilis expansa & & 9 & & & & 2 & 1 & 2 & & & & & & & & & & 14 \\
\hline Palmatolepis gracilis gracilis & 15 & 98 & 9 & 23 & 20 & 39 & 15 & 31 & & & & & & & & & 6 & 256 \\
\hline Palmatolepis marginifera marginifera & & & & & & & & & & & & & & & & & 28 & 28 \\
\hline Palmatolepis minuta minuta & & & & & & & & & & & & & & & & & 4 & 4 \\
\hline Palmatolepis minuta wolskae & & & & & & & & & & & & & & & & 1 & & 1 \\
\hline Palmatolepis perlobata postera & & 4 & & & & & & & & & & & & & & & & 4 \\
\hline Palmatolepis perlobata schindewolfi & 11 & 29 & 1 & & & & & & & & & & & & & & 19 & 60 \\
\hline Polygnathus biconstrictus & & & & & & & & & & & & & 6 & 6 & & & & 12 \\
\hline Polygnathus bicristatus & & & & & & & & & & & & & 43 & 9 & & & & 52 \\
\hline Polygnathus communis communis & 1 & & & 1 & 5 & & & & 8 & 5 & 44 & & 1 & & & & & 65 \\
\hline Polygnathus communis dentatus & & & & & & & & & & & & & & 13 & & & & 13 \\
\hline Polygnathus communis renatae & & & & & & & & 4 & & 11 & 3 & 7 & 9 & & & & & 34 \\
\hline Polygnathus diversus & & & & & & & & & & & & & & & & & 1 & 1 \\
\hline Polygnathus glaber glaber & & & & & & & & & & & & & & & & & 9 & 9 \\
\hline Polygnathus granulosus & 1 & 1 & & & & & & & & & & & & & & & & 2 \\
\hline P. nodocostatus nodocostatus & & & & & & & & & & & & & & & & & 1 & 1 \\
\hline Polygnathus nuragicus & & & & & & & & & & & & & 30 & & & & & 30 \\
\hline Polygnathus perplexus & & 1 & & & & & & & & & & & & & & & & 1 \\
\hline Polygnathus purus purus & & & & & & & & & 1 & 1 & 8 & 46 & 77 & 63 & & & & 196 \\
\hline Polygnathus styriacus & 6 & & & & & & & & & & & & & & & & & 6 \\
\hline Polygnathus tenuiserratus & & & & & & & & & & & & & 127 & 33 & & & & 160 \\
\hline Polygnathus vogesi & & & & & 1 & & & & & & & & & & & & & 1 \\
\hline Protognathodus collinsoni & & & & & & & & & & 4 & 8 & & & & & & & 12 \\
\hline Protognathodus kockeli & & & & & & & & & & & 15 & 7 & & 7 & & & & 29 \\
\hline Protognathodus kuehni & & & & & & & & & & & 7 & 3 & & & & & & 10 \\
\hline Protognathodus meischneri & & & & & & & & & & & 9 & & & 3 & & & & 12 \\
\hline Pseudopolygnathus cf. nudus & & & & & & & & & & & & & & 6 & & & & 6 \\
\hline Pseudopolygnathus dissimilis & & & 16 & & & & & & & & & & & & & & & 16 \\
\hline
\end{tabular}




\begin{tabular}{|c|c|c|c|c|c|c|c|c|c|c|c|c|c|c|c|c|c|c|}
\hline \multirow[b]{3}{*}{ Species } & \multicolumn{10}{|c|}{ Famennian } & \multicolumn{4}{|c|}{ Tournaisian } & \multicolumn{3}{|c|}{ Famennian } & \multirow{3}{*}{ Total } \\
\hline & \multirow{2}{*}{ 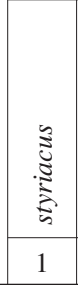 } & \multicolumn{2}{|c|}{ 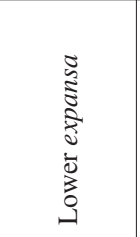 } & \multirow[t]{2}{*}{ 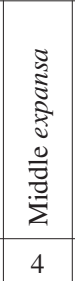 } & \multicolumn{4}{|c|}{ 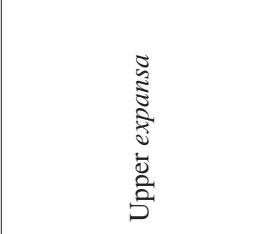 } & \multicolumn{2}{|c|}{ 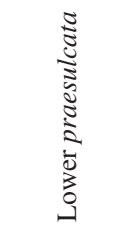 } & \multicolumn{2}{|c|}{ 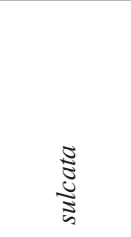 } & \multirow[t]{2}{*}{ 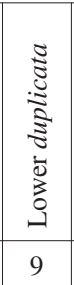 } & \multirow[t]{2}{*}{ 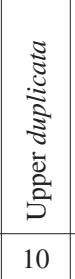 } & \multirow{2}{*}{$\frac{\sigma \cdot}{10 \mathrm{~A}}$} & & 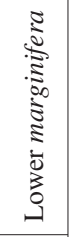 & \\
\hline & & 2 & 3 & & 5 & 6 & $6 \mathrm{~A}$ & $6 \mathrm{~B}$ & $6 \mathrm{C}$ & 7 & 8 & $8 \mathrm{~A}$ & & & & 11 & 12 & \\
\hline Pseudopolygnathus granulobatus & & & & 12 & & & & & & & & & & & & & & 12 \\
\hline Pseudopolygnathus granulosus & & & & 1 & & & & & & & & & & & & & & 1 \\
\hline Ps. marburgensis trigonicus & & & & & 2 & 5 & & 1 & & & & & & & & & & 8 \\
\hline Pseudopolygnathus primus & & & & & & & & & cf. & & & 2 & 24 & & & & & 27 \\
\hline Pseudopolygnathus triangulus & & & & & & & & & & & & & & 20 & & & & 20 \\
\hline Siphonodella bransoni & & & & & & & & & & & & & 1 & & & & & 1 \\
\hline Siphonodella carinthiaca & & & & & & & & & & & & & & 1 & & & & 1 \\
\hline Siphonodella cooperi M1 & & & & & & & & & & & & & & 1 & & & & 1 \\
\hline Siphonodella duplicata & & & & & & & & & & & & & 4 & 2 & & & & 6 \\
\hline Siphonodella praesulcata & & & & & & & & & 2 & & & & & & & & & 2 \\
\hline Siphonodella sulcata & & & & & & & & & & & & & & 2 & & & & 2 \\
\hline Polygnathus sp. A & & & & & & & & & & & & & 11 & & & & & 11 \\
\hline Polygnathus sp. B & & & & & & & & & & & & & 4 & & & & & 4 \\
\hline Bispathodus sp. & & & & & & 1 & & 2 & & & & & & & & & & 3 \\
\hline Branmehla sp. & & & & & & & 7 & 8 & & & & & & & & & 1 & 16 \\
\hline Palmatolepis sp. & 10 & & & & & & & & & & & & & & & 4 & 43 & 57 \\
\hline Polygnathus sp. & 1 & & & & 1 & & & 1 & 3 & 10 & 15 & 20 & 3 & 51 & & 1 & 12 & 118 \\
\hline Pseudopolygnathus sp. & & & & 2 & 4 & 3 & 2 & 1 & 1 & 1 & & 2 & & 3 & & & & 19 \\
\hline Ramiforms & 53 & 20 & 4 & 10 & 23 & 46 & 27 & 40 & 6 & 26 & 36 & 20 & 38 & 22 & & & 30 & 401 \\
\hline Unidentified & & 82 & 14 & 7 & 18 & & & 9 & 6 & 1 & & 7 & 15 & & & 13 & & 172 \\
\hline Total & 102 & 283 & 66 & 76 & 204 & 285 & 114 & 217 & 28 & 66 & 165 & 125 & 405 & 242 & 0 & 23 & 191 & 2592 \\
\hline Weight & 1.3 & 2.0 & 1.7 & 2.1 & 2.3 & 1.4 & 0.8 & 2.3 & 2.9 & 1.2 & 1.8 & 1.3 & 1.5 & 2.2 & 0.4 & 1.0 & 3.0 & 29.2 \\
\hline Abundance & 78.5 & 141.5 & 38.8 & 36.2 & 88.7 & 203.6 & 142.5 & 94.3 & 9.7 & 55.0 & 90.2 & 96.2 & 270.0 & 110.0 & 0.0 & 23.0 & 63.7 & 88.7 \\
\hline
\end{tabular}

(sample 4) is discriminated by the entry of the marker Bispathodus aculeatus aculeatus. The abundance ratio shows an equity between the genus Bispathodus, Pseudopolygnathus and Palmatolepis.

The Upper expansa Zone. - The Upper expansa Zone (samples 5-6B) is recognized by the first occurrence of the marker Bispathodus ultimus. Pseudopolygnathus marburgensis trigonicus and Polygnathus vogesi are exclusive of this zone. Spathognathodids, mainly Bispathodus and Branmehla, are dominant, and Branmehla suprema is especially abundant in the upper part of the zone.

The Lower praesulcata Zone. - The entry of Siphonodella praesulcata in sample BTE 6C allows the discrimination of the Lower praesulcata Zone. Polygnathus communis renatae, Po. purus and Pr. collinsoni enter, and Branmehla inornata has its last occurrence within this zone. Genus Polygnathus, relatively rare in the lower part of the section, becomes the dominant genus starting from this zone.
The Upper praesulcata Zone. - The Upper praesulcata Zone has not been recognized in this section, as in other sections of the same age in Sardinia.

The sulcata Zone. - Since the marker Siphonodella sulcata is missing, the occurrence of Protognathodus kuehni in sample BTE 8 allows attributing the interval above the Hangenberg equivalent shales and below the first occurrence of Siphonodella duplicata to the sulcata Zone. Kaiser et al. (2009) used the same taxon to identify the base of the Carboniferous and named this zone sulcatalkuehni Zone.

Subspecies of Polygnathus communis and Protognathodids are very abundant. Pseudopolygnathus primus has its first occurrence within this zone.

The Lower duplicata Zone. - The Lower duplicata Zone is documented by the entry of the marker Siphonodella duplicata in sample BTE 9. Siphonodella bransoni (= Si. duplicata M1), Polygnathus nuragicus and Polygnathus sp. A here have their only occurrence in the section; Po. teniuserratus, 


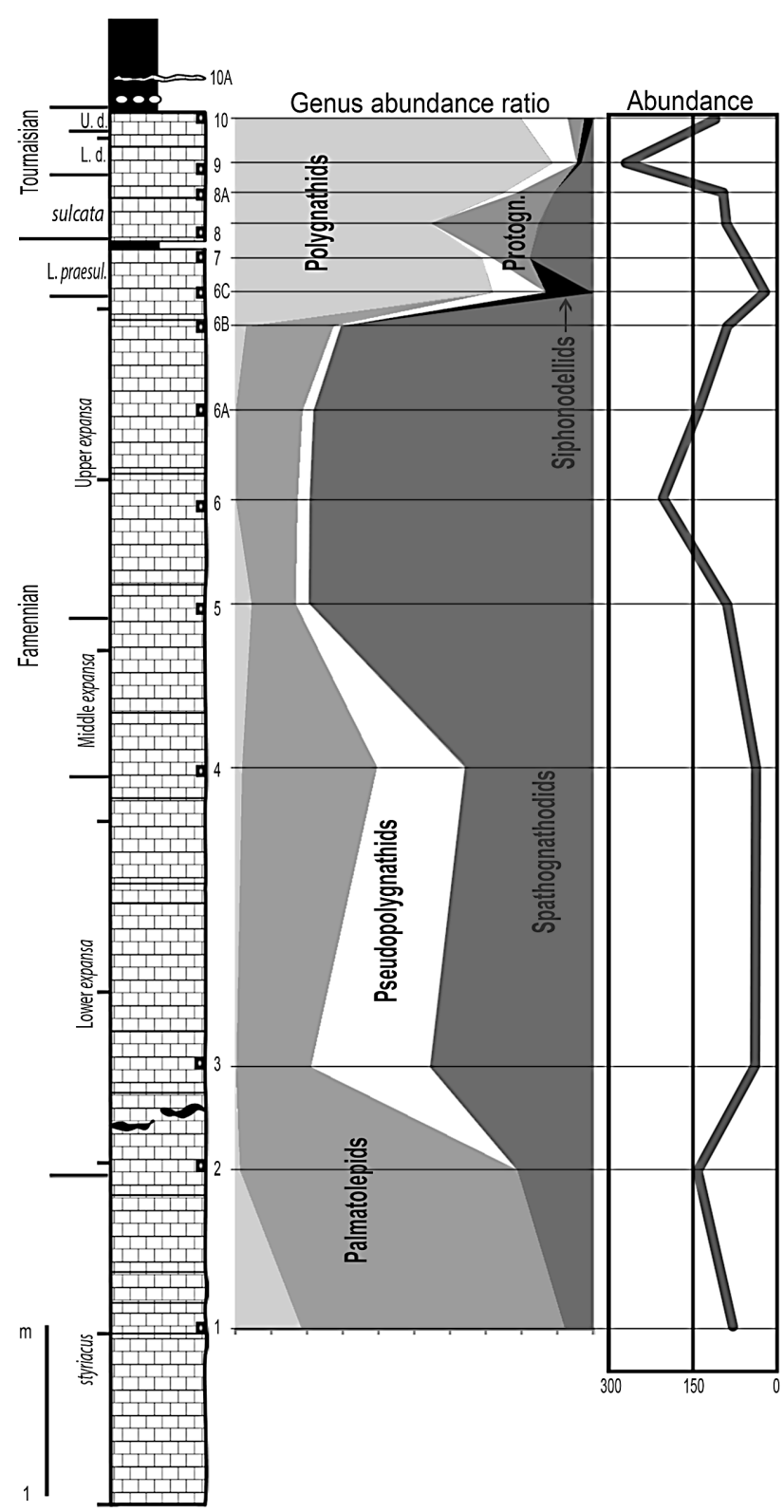

Figure 4. Genus abundance ratio and total abundance of conodonts in the Bruncu Bullai section. The upper part, above the tectonic duplication, is not reported. Spathognathodids includes genera Bispathodus, Mehlina and Branmehla. Abbreviation of biozones: L. praesul. $=$ Lower praesulcata; L. $d .=$ Lower duplicata; U.d.= Upper duplicata .

Polygnathus bicristatus and Po. biconstrictus enter, whereas Po. communis renatae has its last occurrence.

Polygnathus is the dominant genus. In this zone Siphonodella is present whilst Protognathodus is absent.

The Upper duplicata Zone. - The Upper duplicata Zone is discriminated in sample BTE 10 by the occurrence of Si. cooperi M1 and of Si. carinthiaca. Pseudopolygnathus triangulus and Po. communis dentatus have their only occurrence in the section.

\section{Notes on the Hangenberg Event}

The Hangenberg Event is one of the major extinction events of the Phanerozoic and is expressed by a sudden anoxic and transgressive event, followed by rapid cooling and a glaciation pulse on Gondwana leading to global regression (Kaiser et al. 2008). In most localities it corresponds to the deposition of black shales ("Hangenberg Shales" in Germany, or Hangenberg equivalent elsewhere), but at places the carbonate deposition is continued throughout the event (i.e. Grüne Schneid section in the Carnic Alps, Schönlaub et al. 1988). The deposition of sandstone immediately before the main event represents a low stand documented in several regions (Kaiser 2005).

Among conodonts, the severe extinction and decrease of abundance is also connected with a change from a palmatolepid-bispathodid biofacies to a protognathodidpolygnathid biofacies during the initial phase of the Hangenberg Event (Kaiser 2005).

In the BTE section a strong decrease of abundance is observed in sample BTE 6C (Lower praesulcata Zone), where some typical Famennian pelagic taxa are not present, such as Bispathodus costatus, Bispathodus ultimus and Palamatolepis gracilis gracilis. This low diverse fauna occurs also in sample BTE 7, collected just below the shale level. Also, even if the rock is still represented by limestone, the terrigenous content of beds BTE 6C and 7 is slightly higher than the rest of the section. Therefore, all these data (the impoverished fauna, the change in the biofacies and lithology) may suggest that the early phase of the Hangenberg crisis already start in bed of sample BTE 6C.

\section{On the abundance of Protognathodus and Siphonodella}

Protognathodus and Siphonodella are, in general, not abundant in the conodont association, but their occurrence is very important since the zonation across the Devonian/Carboniferous boundary is based on first occurrence of species of these genera.

In the Bruncu Bullai section the two genera do not generally co-occur: in sample BTE 6C only Siphonodella have been found; in samples BTE 7-8A Protognathodus is present, while Siphonodella is absent; in sample BTE 9 (Lower duplicata Zone) Siphonodella is present, but Protognathodus is missing; both taxa co-occur only in sample BTE 10 (Upper duplicata Zone). Such irregular occurrence of these genera is documented also in other sections around the world, where in some levels Protognathodus only is present, and in others only Siphonodella: i.e. Grüne Schneid (Schönlaub et al. 1988, 1992; Kaiser 2005, 2007), Milles (Kaiser 2005), Puech de la Suque (Kaiser 2005), 

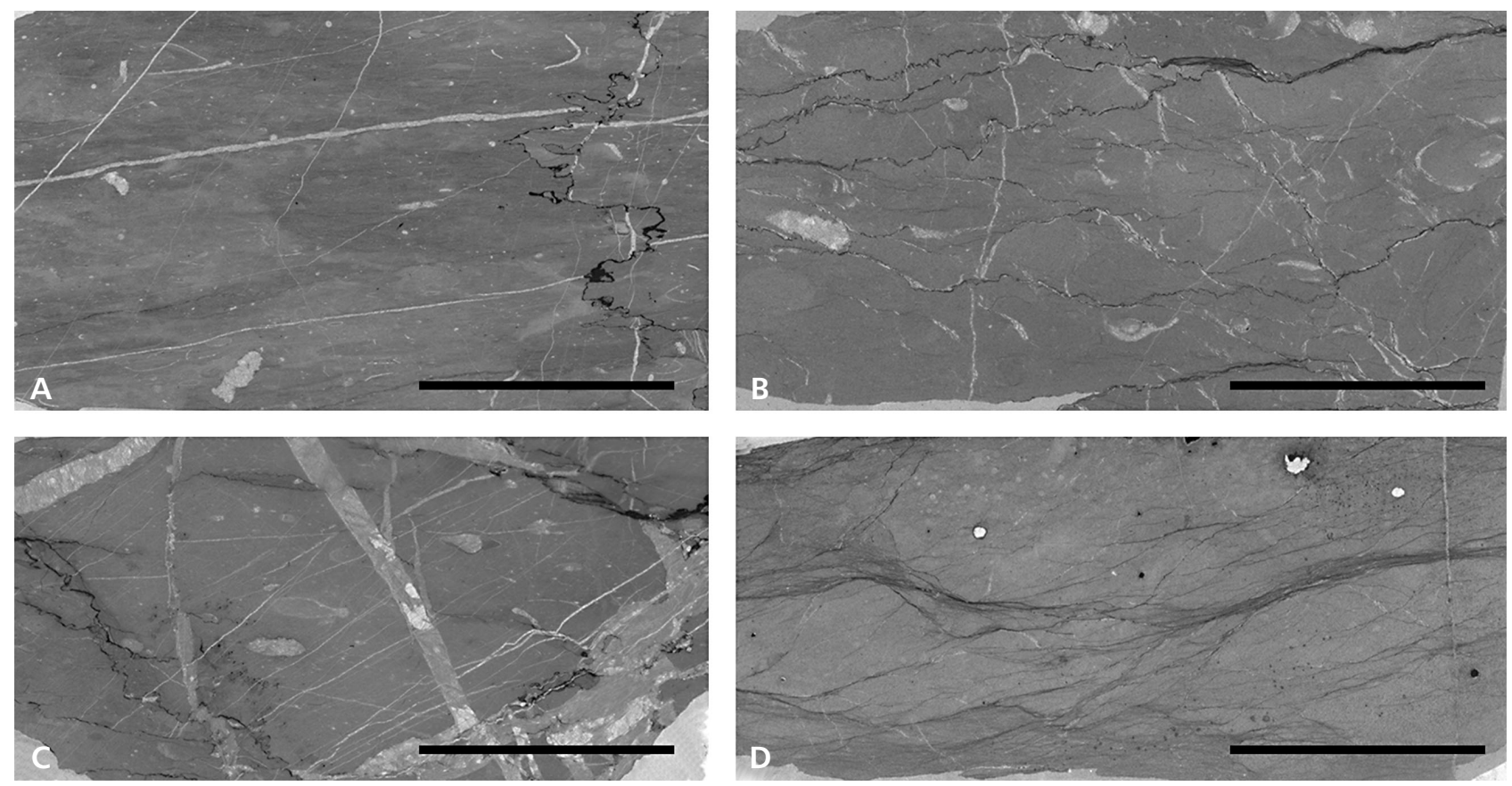

Figure 5. Microfacies of the Bruncu Bullai section. - A - grey wackestone, sample BTE 5. • B - grey wackestone with fossil remains and calcite ricristallization, in sample $\mathrm{BTE} 7 . \bullet \mathrm{C}-$ a grey wackestone with fossil remains and stylolite structures, in sample BTE 8 . $\bullet$ D grey wackestone with tension gashes, sample BTE 10A. Scale bar $1 \mathrm{~cm}$.

Oese (Kaiser 2005), Hasselbachtal (Kaiser 2005), Scharfenberg (Clausen et al. 1989), Seiler-Schurf III-I (Clausen et al. 1989). In other sections (i.e. La Serre E', Kaiser 2005; Trolp, Ebner 1980, Kaiser 2005) the two taxa occur together in almost all samples, but with great variation in relative abundance. In first approximation this "alternate" occurrence of the two genera is more common in the Upper praesulcata and sulcata zones, and somewhere up to the Lower duplicata Zone, whereas they occur together in the Upper duplicata Zone.

These sections are characterized by different sedimentary and palaeogeographic contests, and therefore the pattern of occurrence of Siphonodella and Protognathodus cannot be explained with the conventional biofacies model (Ziegler \& Sandberg 1984) where Protognathodids were considered shallow water taxa and Siphonodellids more pelagic taxa. Kaiser et al. (2005) suggested that the abundance of Protognathodus in the lowermost Carboniferous beds could be related to an opportunistic life-style in deeper environments.

An enhanced model was proposed by Kaiser et al. (2008, 2009), who studied in detail the occurrence of the main genera across the Devonian/Carboniferous boundary in selected sections in the Pyrenees (Milles), Carnic Alps (Kronhofgraben) and Graz Palaeozoic (Trolp) and explained the genus occurrence pattern by changes in the depositional basins connected with sea level variations. However, this does not explain the distribution in other sections where there is no lithological evidence of eustatic variations (i.e. Grüne Schneid). Corradini et al. (2011, p. 20) suggested "the occurrence of the Prothognathodus fauna can be related to biotic opportunism during a rise in sea level in the latest Devonian".

Considering the peculiar pattern of the occurrence of Protognathodus and Siphonodella in pelagic environment, their occurrence in sediments across the Devonian/Carboniferous boundary was likely influenced by ecological factors as competition and feeding.

\section{Comments on the Devonian/Carboniferous boundary in Sardinia}

Beside the Bruncu Bullai section, the Monte Taccu section (Corradini et al. 2003, Mossoni et al. 2013) is the only other locality so far known exposing strata across the Devonian/Carboniferous boundary in Sardinia. It is located about $10 \mathrm{~km}$ west of the Bruncu Bullai section.

As in the Bruncu Bullai section, the Hangenberg equivalent shales are represented by a narrow bed, $2-4 \mathrm{~cm}$ thick of dark shaley limestone in the Monte Taccu section; above about 1 meter of limestone of Carboniferous age is tectonically covered by Ordovician sandstones. On the basis of conodonts in the Monte Taccu section the youngest resolvable Devonian bed belongs to the Lower praesulcata Zone, and the oldest Carboniferous strata are Lower duplicata Zone. The Upper praesulcata and the sulcata zones are not present. The youngest Carboniferous limestone 
documented belongs to the Upper duplicata Zone (Corradini et al. 2003, Mossoni et al. 2013).

Even if the upper part of the sections are very similar, exposing about $80 \mathrm{~cm}$ of Carbonifeous limestone, a difference in age is reported for the bed just above the Hangenberg equivalent shales: in the Bruncu Bullai section it belongs to the sulcata Zone, while in the Monte Taccu section the Lower duplicata Zone is documented by the occurrence of a single specimen of the marker Siphonodella duplicata in sample MT X2. However, Siphonodella is very rare in the lowermost Carboniferous of Sardinia, and at the Bruncu Bullai section no specimens of genus Siphonodella have been found in samples BTE 8 and BTE 8A, attributed to the sulcata Zone on the presence of Protognathodus kuehni, that ranges from the base of the sulcata Zone to the sandbergi Zone (Corradini et al. 2011). The conodont association of these beds cannot exclude that these levels may belong to the Lower duplicata Zone, as in the Monte Taccu section, as suggested by preliminary data on magnetic susceptibility (MS). However this hypothesis can be confirmed only by finding specimens of Si. duplicata in these beds.

\section{Systematic palaeontology}

The conodont collection is housed in the Museum of Palaeontology "Domenico Lovisato" of Cagliari University (MDLCA); catalog numbers of figured elements (Figs 6, 7) can be obtained from the plate caption.

Systematic notes are restricted to new species and necessary taxonomic and/or biostratigraphic remarks. Taxonomy is focused on P1 element only. For suprageneric classification, the scheme proposed by Sweet (1988) is followed.

Order Ozarkodinida Dzik, 1976

Family Polygnathidae Bassler, 1925

\section{Genus Polygnathus Hinde, 1879}

Type species. - Polygnathus dubius Hinde, 1879.

\section{Polygnathus bicristatus sp. nov.} Figure $6 \mathrm{~A}-\mathrm{G}$

2005 Polygnathus sp. Kaiser, pl. 2, figs 3, 4.

2009 Polygnathus sp. B Kaiser et al., pl. 2, figs 7, 8.

Holotype. - P1 element MDLCA 30280, illustrated in Fig. 6C, D.

Type horizon and locality. - Bruncu Bullai section, Sardinia, Italy; bed of sample BTE 9.

Etymology. - From Latin cristatus (= with a crest), referring to the occurrence of the two rows of nodes in the anterior part of the platform

Diagnosis. - Species of Polygnathus with a subtriangular elongated platform, strong ornamentation made up of transversal ridges. A row of well-developed nodes is present in the anterior part of each side of the platform. The basal cavity is small, elongated and extends under the free blade.

Description. - Polygnathus bicristatus have a subtriangular elongated and slightly asymmetrical platform. The ornamentation is constituted by distinctive transversal ridges that in their inner part almost reach the carina. The ridges tend to be more perpendicular to the carina in the central part of the platform, and with a sharp angle in the posterior part. On the anterior part a row of 2-3 large nodes is present on each side of the platform diverging anteriorly from the carina, forming a structure similar to a collar. The part of the platform between the carina and these anterior rows of nodes is unornamented.

The basal cavity is located under the anterior part of the platform; it is narrow and elongated, and extends as

Figure 6. A, B - Polygnathus bicristatus sp. nov.; upper and lower views of MDLCA 30279, sample BTE 9 (Lower duplicata Zone). - C, D - Polygnathus bicristatus sp. nov.; upper and lower views of the holotype MDLCA 30280, sample BTE 9 (Lower duplicata Zone). -E - Polygnathus bicristatus sp. nov.; upper view of MDLCA 30281, sample BTE 9 (Lower duplicata Zone). • F - Polygnathus bicristatus sp. nov.; upper view of MDLCA 30282, sample BTE 9 (Lower duplicata Zone). $\bullet \mathrm{G}-$ Polygnathus bicristatus sp. nov.; upper view of MDLCA 30283, sample BTE 9 (Lower duplicata Zone). $\bullet \mathrm{H}$ - Polygnathus sp. A; upper-lateral view of MDLCA 30284, sample BTE 9 (Lower duplicata Zone). I - Polygnathus sp. A; upper-lateral view of MDLCA 30285, sample BTE 9 (Lower duplicata Zone). • J - Polygnathus sp. A; upper view of MDLCA 30286, sample BTE 9 (Lower duplicata Zone). $\bullet \mathrm{K}$ - Polygnathus sp. A; lower view of MDLCA 30287, sample BTE 9 (Lower duplicata Zone). $\bullet \mathrm{L}-$ Polygnathus sp. B; upper view of MDLCA 30288, sample BTE 9 (Lower duplicata Zone). M, N - Polygnathus nuragicus sp. nov.; upper and lower views of MDLCA 30289 , sample BTE 9 (Lower duplicata Zone). • O, P - Polygnathus nuragicus sp. nov.; upper-lateral and lower views of MDLCA 30290, sample BTE 9 (Lower duplicata Zone). $\bullet \mathrm{Q}, \mathrm{R}-$ Polygnathus nuragicus sp. nov.; lateral and lower views of the holotype MDLCA 30291, sample BTE 9 (Lower duplicata Zone). • S - Polygnathus nuragicus sp. nov.; upper view of MDLCA 30292, sample BTE 9 (Lower duplicata Zone). • T - Pseudopolygnathus sp. A; upper view of MDLCA 30293, sample BTE 10 (Upper duplicata Zone). $\bullet U, \mathrm{~V}-$ Pseudopolygnathus granulobatus sp. nov.; upper and lower views of the holotype MDLCA 30294, sample BTE 4 (Middle expansa Zone). - W, X - Pseudopolygnathus granulobatus sp. nov.; upper view of MDLCA 30295, sample BTE 4 (Middle expansa Zone). 


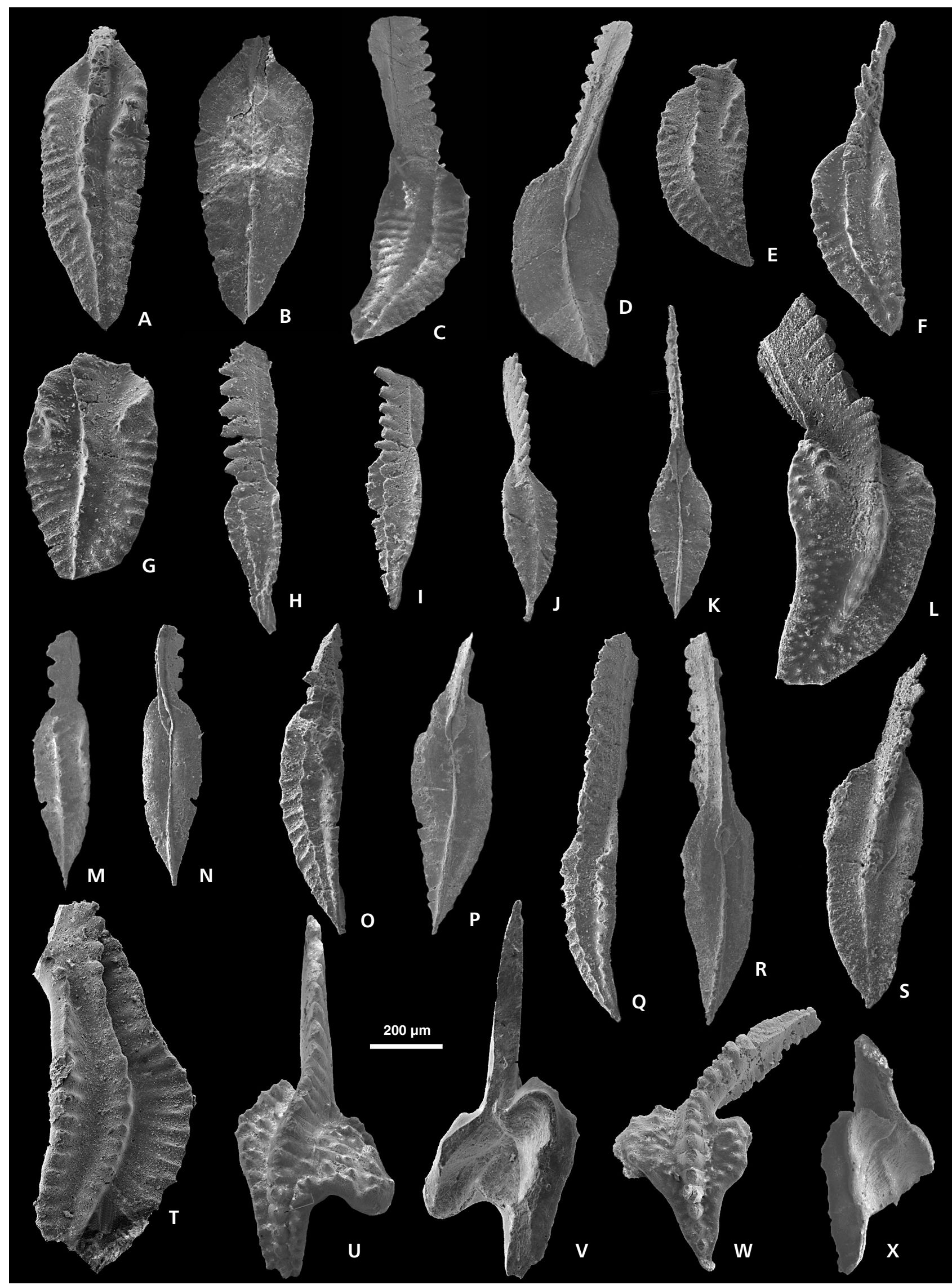


a narrow groove under the proximal part of the free blade. The keel is weakly developed posterior of the basal cavity and becomes higher towards the posterior end.

Remarks. - In some elements the ridges on the posterior part of the platform are weak and look to be constituted by narrowly arranged nodes. The size of the anterior rows of nodes can be slightly different on the two sides, being one more developed that the other.

Polygnathus bicristatus is distinguished from the other species of Polygnathus because of the characteristic ornamentation and the thin and elongated basal cavity. It differs from Polygnathus sp. B because the latter has a somewhat larger platform bearing randomly arranged nodes, instead of ridges, on its posterior part.

Beside Sardinia, this species have been documented in Montagne Noire by Kaiser (2005) and Kaiser et al. (2009). A few incomplete specimens of this species occur also in the collection from Monte Taccu (Corradini et al. 2003), but were not described by the authors.

Studied material. - 52 elements from samples BTE 9, 10.

Occurrence. - From the Lower duplicata Zone to the Upper duplicata Zone. The elements reported in the synonymy list came from the Lower duplicata Zone.

\section{Polygnathus communis renatae Corradini \& Spalletta (in Corradini et al.), 2003 \\ Figure $7 \mathrm{U}$}

2003 Polygnathus communis renatae $\mathrm{n}$. ssp. Corradini \& Spalletta, p. 236, pl. 2, figs 1-5.
2013 Polygnathus communis renatae Corradini \& Spalletta. - Mossoni et al., fig. 3.6.

Remarks. - Polygnathus communis renatae is characterized by the presence of a single node on the anterior lateral margin on each side of the platform. The presence of these nodes allows distinguishing it from all other subspecies of Po. communis. The taxon is up to now known only in Sardinia.

Studied material. - 34 elements from samples BTE 6B-10.

Occurrence. - From the Lower praesulcata Zone (Corradini \& Spalletta in Corradini et al., 2003) to the Lower duplicata Zone (this paper).

\section{Polygnathus nuragicus sp. nov. Figure 6M-S}

Holotype. - P1 element MDLCA 30291, illustrated in Fig. 6Q, R.

Type horizon and locality. - Bruncu Bullai section, Sardinia, Italy; bed of sample BTE 9.

Etymology. - From the shape of the element that recall an ancient weapon of Nuragic people, the ancient population of Sardinia.

Diagnosis. - Species of Polygnathus characterized by a lanceolate and elongated platform, with thickened margins in the anterior part. The platform surface is ornamented by small ridges. The small basal cavity is located under the

Figure 7. A - Polygnathus styriacus Ziegler, 1957; upper view of MDLCA 30296, sample BTE 1 (styriacus Zone). • B - Palmatolepis perlobata postera Ziegler, 1960; upper view of MDLCA 30297, sample BTE 2 (Lower expansa Zone) • C - Palmatolepis gracilis expansa Sandberg \& Ziegler, 1979; upper view of MDLCA 30298, sample BTE 2 (Lower expansa Zone). D - Bispathodus jugosus (Branson \& Mehl, 1934a); upper view of MDLCA 30299, sample BTE 4 (Middle expansa Zone). $\bullet$ E - Bispathodus costatus (Branson, 1934); upper view of MDLCA 30300, sample BTE 5 (Upper expansa Zone). $\bullet$ F - Bispathodus spinulicostatus (Branson, 1934); upper view of MDLCA 30301, sample BTE 6 (Upper expansa Zone). • G - Bispathodus ultimus (Bischoff, 1957); upper view of MDLCA 30302, sample BTE 5 (Upper expansa Zone). • H, I - Branmehla werneri (Ziegler, 1957); lateral and upper views of MDLCA 30303, sample BTE 2 (Lower expansa Zone). • J - Branmehla suprema (Ziegler, 1962); upper view of MDLCA 30304, sample BTE 6 (Upper expansa Zone). - K - Pseudopolygnathus marburgensis trigonicus Ziegler, 1962; upper view of MDLCA 30305, sample BTE 5 (Upper expansa Zone). • L - Polygnathus tenuiserratus Corradini \& Spalletta (in Corradini et al.), 2003; upper view of MDLCA 30306, sample BTE 10 (Upper duplicata Zone). - M - Pseudopolygnathus cf. nudus Pierce \& Langenheim, 1974; upper view of MDLCA 30307, sample BTE 10 (Upper duplicata Zone). • N - Polygnathus communis dentatus Druce, 1969; upper view of MDLCA 30308, sample BTE 10 (Upper duplicata Zone). $\bullet$ O Polygnathus purus purus Voges, 1959 ; upper view of MDLCA 30309, sample BTE 8A (sulcata Zone). • P - Siphonodella duplicata (Branson \& Mehl, 1934b); upper view of MDLCA 30310, sample BTE 10 (Upper duplicata Zone). Q - Siphonodella duplicata (Branson \& Mehl, 1934b); upper view of MDLCA 303111, sample BTE 10 (Upper duplicata Zone). - R - Siphonodella carinthiaca Schönlaub, 1969; upper view of MDLCA 30312, sample BTE 10 (Upper duplicata Zone). • S - Siphonodella cooperi Hass, 1959; upper view of MDLCA 303113, sample BTE 10 (Upper duplicata Zone). •T - Siphonodella sulcata Huddle, 1934; upper view of MDLCA 303114, sample BTE 10 (Upper duplicata Zone). • U - Polygnathus communis renatae Corradini \& Spalletta (in Corradini et al.), 2003; upper view of MDLCA 30315, sample BTE 8 (sulcata Zone). • V - Pseudopolygnathus triangulus Voges, 1959; upper view of MDLCA 30316, sample BTE 10 (Upper duplicata Zone). -W - Protognathodus meischneri Ziegler, 1969; upper view of MDLCA 30317, sample BTE 8 (sulcata Zone). • X - Protognathodus kockeli Bischoff, 1957; upper view of MDLCA 30318, sample BTE 8 (sulcata Zone). • Y - Protognathodus collinsoni Ziegler, 1969; upper view of MDLCA 30319, sample BTE 8 (sulcata Zone). - Z- Protognathodus kuehni Ziegler \& Leuteritz, 1970; upper view of MDLCA 30320, sample BTE 8 (sulcata Zone). 


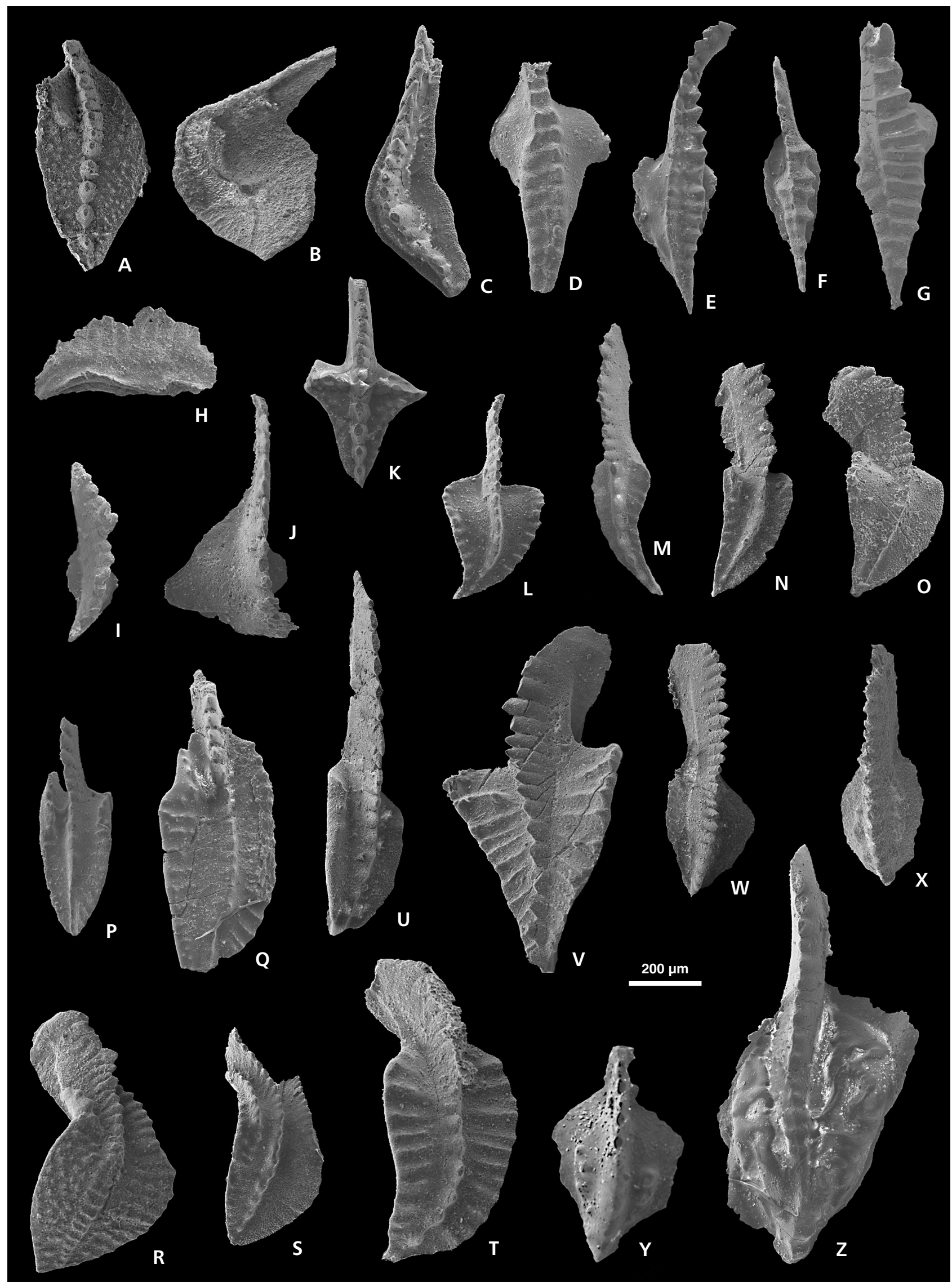


anterior part of the platform and is followed posteriorly by a keel that reaches the posterior end.

Description. - Polygnathus nuragicus has an elongated platform with evident thickened margins in the anterior part. The surface is ornamented with small but distinctive ridges. The carina extends throughout the platform; is higher and made of fused nodes in the anterior part, becoming very low, almost to disappear, close to the posterior end. The free blade is high and as long as the platform.

The basal cavity is small and located under the anterior part of the platform. A narrow keel starts from the basal cavity and reaches the posterior end; it is low under the central part of the platform and became higher posteriorly. A weak depression is present under the central part of the platform.

Remarks. - Polygnathus nuragicus is distinguished from representatives of Po. communis group because of the lack of the well developed depression just posterior of the basal cavity, and because the keel starts from the basal cavity. It differs from Po.tenuiserratus for the shape of the platform and because the latter has the ornamentation limited to the external margins; it is different from Po. biconstrictus because the latter has a constricted anterior part of the platform with folded upward margins.

Studied material. - 30 elements from sample BTE 9.

Occurrence. - Lower duplicata Zone.

\section{Polygnathus sp. A}

Figure $6 \mathrm{H}-\mathrm{K}$

Description. - The elements assigned to this species are slender and have a lanceolate platform tipped in the posterior part. The anterior margins of the platform reach the carina with a sharp angle. The platform has reinforced edges at its point of maximum width. Posterior end of the platform tipped.

The ornamentation is weak and made up of transversal ridges stronger close to the lateral margins and disappearing toward the carina. The carina is made by partly fused small nodes that decrease in height from the anterior platform to the posterior end. The free blade is more or less as long as the platform, and bears discrete laterally compressed denticles.

The small basal cavity has an oval shape with raised thickened margins and is located under the anterior part of the platform. A keel extends posteriorly of the basal cavity up to the posterior tip.

Remarks. - In a few elements the posterior part of the platform is so narrow that the end of the carina looks to form a short free blade. Polygnathus sp. A is distinguished from Po. nuragicus because the latter has thickened margins in the anterior part of the platform. The lanceolate elongated platform distinguish Po. sp. A from Po. tenuiserratus.

Studied material. - 9 elements from sample BTE 9.

Occurrence. - Lower duplicata Zone.

\section{Polygnathus sp. B}

Figure 6L

Description. - The elements assigned to this species have a subtriangular elongated and slightly asymmetrical platform. The ornamentation is strong on the anterior and central part of the platform where it consists of evident transversal ridges that interiorly extend almost up to the carina. In the posterior part the platform is covered by nodes randomly distributed. On the anterior part of the platform a row of 2-3 pronounced nodes is present on each side of the platform and diverge anteriorly from the carina. The part of the platform between the carina and these anterior rows of nodes is unornamented.

The basal cavity, located under the anterior part of the platform, is narrow and elongated, and extends as a narrow groove under the proximal part of the free blade. The keel is weakly developed posterior of the basal cavity and it become higher in the posterior part.

Remarks. - Polygnathus sp. B is distinguished from Polygnathus bicristatus by the generally wider platform and the ornamentation constituted by randomly arranged nodes on the posterior part of the platform.

Studied material. - 4 elements from sample BTE 9.

Occurrence. - Lower duplicata Zone.

\section{Genus Pseudopolygnathus, Branson \& Mehl, 1934a}

\section{Pseudopolygnathus granulobatus sp. nov.} Figure 6U-Y

Holotype. - P1 element MDLCA 30294, illustrated in Fig. 6U, V.

Type horizon and locality. - Bruncu Bullai section, Sardinia, Italy; bed of sample BTE 4.

Etymology. - From Latin granulosus (= covered by nodes) and lobatus (= with a lobe), referring to the shape of the platform. 
Diagnosis. - A species of Pseudopolygnathus characterized by an asymmetrical, strongly heart-shaped, ornamented platform, with a distinctive lateral lobe. The platform is large in the anterior part and narrow posteriorly. The basal cavity is large and extends below the whole element.

Description. - The elements assigned to Ps. granulobatus have a subtriangular or heart-shaped platform, larger in the anterior part of the element and narrow posteriorly. Posterior end tipped. A distinct lobe is present on one side of the platform.

The surface of the platform is strongly ornamented with nodes randomly disposed on the anterior part and more or less aligned with the lateral margin on the narrow posterior part. The carina, constituted by strong nodes, reaches the posterior end of the element; it is high on the anterior part of the platform and decreases in height posteriorly, in connection with the narrowing of the platform. Anteriorly the carina continues in the high free blade that bears discrete denticles.

The basal cavity is wide and extends below the whole platform.

Remarks. - Pseudopolygnathus granulobatus is distinguished from Ps. granulosus by the pronounced lobe at one side of the platform and from Ps. marburgensis trigonicus because the latter shows a row of distinctive nodes in the anterior part of the platform and has a distinctive basal cavity. The ornamentation is more pronounced in the large elements, than in the small ones.

Studied material. - 12 elements from sample BTE 4.

Occurrence. - Middle expansa Zone.

\section{Conclusions}

The main results of this work on the Bruncu Bullai section can be summarized as follows:

1. fifty-seven taxa, between species and subspecies, belonging to Branmehla, Bispathodus, Icriodus, Mehlina, Palmatolepis, Polygnathus, Protognathodus, Pseudopolygnathus, and Siphonodella have been recognized;

2. a new species of Pseudopolygnathus (Ps. granulobatus), two of Polygnathus (Polygnathus bicristatus, Polygnathus nuragicus) are described and illustrated. Two more taxa of Polygnathus are left in open nomenclature;

3 . the range of Polygnathus communis renatae have been extended to the Lower duplicata Zone;

4. on the basis of the relative abundance of Prothognathus and Siphonodella, a possible ecological control on the occurrence of the two genera is suggested, where competition and feeding are claimed to explain the "alternate" occurrence of the two genera in the latest Famennian and basal Tournaisian;

5. the Hangenberg crisis is supposed to start already in sample BTE 6C, before the shale level;

6. as for regional geology of Sardinia, the presence of black shales with siliceous nodules above the "Clymeniae limestones" is documented. According to field observations this level is tentatively considered as Tournaisian; however more data are necessary for precisely state its age.

\section{Acknowledgements}

Nicola Cotza is deeply acknowledged for his kindness and for the help in the field work. We are grateful to Francesco Cotza and Gesuina Floris for allowing us to work on their property. Giorgio Gasparotto (Bologna) helped in taking SEM photographs of conodonts. The paper was improved thanks to the comments by Jeff Over and Sandra Kaiser.

AM gratefully acknowledges Sardinia Regional Government for the financial support of his $\mathrm{PhD}$ scholarship (P.O.R. Sardegna F.S.E. "Operational Programme of the Autonomous Region of Sardinia, European Social Fund 2007-2013" - Axis IV Human Resources, Objective 1.3, Line of Activity 1.3.1.). This study was supported by R.A.S. (grants LR7/07 - 2010, Resp. C. Corradini).

This paper is a contribution to the activities of the International Working Group on the Redefinition of the Base of the Carboniferous System, established by the International Commission on Stratigraphy, and to IGCP 596 "Mid Palaeozoic climate and biodiversity".

\section{References}

Bahrami, A., Gholamalian, H., Corradini, C. \& Yazdi, M. 2011. Upper Devonian conodont biostratigraphy of Shams Abad section, Kerman province, Iran. Rivista Italiana di Paleontologia e Stratigrafia 117, 199-209.

Barca, S., Corradini, C. \& Spalletta, C. 2000. Nuovi dati sull'età dei "Calcari a Clymenie" della Sardegna, 25-28. In Cherchi, A. \& Corradini, C. (eds) Crisi biologiche, radiazioni adattative e dinamica delle piattaforme carbonatiche. Accademia Nazionale di Scienze Lettere e Arti di Modena, Collana di Studi 21.

Barca, S., Gnoli, M., Olivieri, R. \& Serpagli, E. 1986. New stratigraphic data and evidence of Lower and Upper Devonian based on conodonts in Sarrabus area (Southeastern Sardinia). Rivista Italiana di Paleontologia e Stratigrafia 92, 299-320.

Barca, S. \& Spalletta, C. 1985. Nuove osservazioni sul conglomerato di Villasalto (Carbonifero inferiore-medio, Sardegna). Giornale di Geologia S3 46, 25-32.

BASSLER, R. 1925. Classification and stratigraphic use of conodonts. Geological Society of America Bulletin 36, 218-220.

BECKER, R.T. 1993. Analysis of ammonoid palaeobiogeography in relation to the global Hangenberg (terminal Devonian) and 
Lower Alum Shale (Middle Tournaisian) events. Annales de la Société Géologique de Belgique 115, 459-473.

Becker, R.T., Hartenfels, S., Aboussalam, Z.S., Tragelehn, H., Brice, D. \& El Hassani, A. 2013. The Devonian-Carboniferous boundary at Lalla Mimouna (Northern Maider) - A progress report, 109-120. In BECKER, R.T., El HASSANI, A. \& TAHIRI, A. (eds) International Field Symposium "The Devonian and Carboniferous of Northern Gondwana" - Morocco 2013. Documents de l'Institut Scientifique, Rabat 27.

Bischoff, G. 1957. Die Conodonten-Stratigraphie des rhenoherzynischen Unterkarbons mit Berücksichtigung der Wocklumeria-Stufe und der Devon/Karbon-Grenze. Abhandlunghen des Hessisches Landesamt für Bodenforschung 84, 115-137.

Branson, E.B. \& Mehl, M.G. 1934a. Conodonts from the Grassy Creek shale of Missouri. Missouri University Studies 8, 171-259.

Branson, E.B. \& Meht, M.G. 1934b. Conodonts from the Bushberg sandstone and equivalent formations of Missouri. Missouri University Studies 4, 265-300.

Branson, E.R. 1934. Conodonts from the Hannibal Formation of Missouri. Missouri University Studies 8, 301-343.

Carmignani, L., Gattiglio, M., Maxia, M., Oggiano, G., Pertusati, P.C. 1986. The geology of Gerrei, 61-72. In Carmignani, L., Cocozza, T., Ghezzo, C., Pertusati, P.C. \& Ricci, C.A. (eds) Guide-book to the excursion on the Paleozoic Basement of Sardinia, IGCP No. 5, Newsletter special issue.

Casier, J.-G., Lethiers, F. \& Préat, A. 2002. Ostracods and sedimentology of the Devonian-Carboniferous stratotype section (La Serre, Montagne Noire, France). Bulletin de l'Institut Royal des Sciences Naturelles de Belgique, Science de la Terre 72, 43-68.

Clausen, C.-D., Leuteritz, K. \& Ziegler, W. 1989. Ausgewählte Profile an der Devon/Karbon-Grenze im Sauerland (Rheinisches Schiefergebirge). Fortschritte in der Geologie vom Rheinland und Westfalen 35, 161-226.

Corradini, C. 1998a. Conodonti del Devoniano Superiore nei "Calcari a Clymeniae" di Villasalto (Sardegna SudOrientale): Tassonomia e Biostratigrafia. $139 \mathrm{pp} . \mathrm{PhD}$ thesis, University of Modena, Italy.

Corradini, C. 1998b. New Devonian (Famennian) taxa of polygnathids and icriodids (conodonts) from Sardinia. Giornale di Geologia 60, Spec. Issue, 89-92.

Corradini, C. 1998c. Famennian conodonts from two sections near Villasalto. Giornale di Geologia 60, Spec. Issue, 122-135.

Corradini, C. 1998d. The middle-late Devonian of Su Nuargi, East of Domusnovas. Giornale di Geologia 60, Spec. Issue, 188-193.

Corradini, C. 2002. The Clymeniae limestone in the Corona Mizziu Sections (SE Sardinia, Italy). Rendiconti della Società Paleontologica Italiana 1, 261-264.

Corradini, C. 2003. Late Devonian (Famennian) conodonts from the Corona Mizziu sections near Villasalto (Sardinia, Italy). Palaeontographia Italica 98, 65-116.

Corradini, C. 2007. Calcari a Clymenie. In Carta Geologica d'Italia 1:50000 - Catalogo delle Formazioni; fascicolo VI Unità tradizionali elo storiche. Quaderni III(7), 298-301.
Corradini, C. 2008. Revision of Famennian-Tournaisian (Late Devonian - Early Carboniferous) conodont biostratigraphy of Sardinia, Italy. Revue de Micropaleontologie 51, 123-132. DOI 10.1016/j.revmic.2007.02.005

Corradini, C., Barca, S. \& Spalletta, C. 2003. Late Devonian-Early Carboniferous conodonts from the "Clymeniae limestones" of SE Sardinia (Italy). Courier ForschungsInstitut Senckenberg 245, 227-253.

Corradini, C. \& Ferretti, A. 2009. The Silurian of the External Nappes (southeastern Sardinia). Rendiconti della Società Paleontologica Italiana 3, 43-49.

Corradini, C., Ferretti, A. \& Serpagli, E. 2002. The Gerrei Tectonic Unit (SE Sardinia, Italy). Rendiconti della Società Paleontologica Italiana 1, 69-76.

Corradini, C., Kaiser, S.I., Perri, M.C. \& Spalletta, C. 2011. Protognathodus (Conodonta) and its potential as a tool for defining the Devonian/Carboniferous boundary. Rivista Italiana di Paleontologia e Stratigrafia 116, 15-28.

Corradini, C., Leone, F., Loi, A. \& Serpagli, E. 2001. Conodont stratigraphy of a highly tectonised Siluro-Devonian section in the San Basilio area (SE Sardinia). Bollettino della Società Paleontologica Italiana 40, 315-323.

Corradini, C., Spalletta, C., Kaiser, S.I. \& Matyja, H. 2013. Overview of conodonts across the Devonian/Carboniferous boundary. Asociación Paleontológica Argentina, Publicación Especial 13, 13-16.

Derycke, C., Spalletta, C., Perri, M.C. \& Corradini, C. 2008. Famennian chondrichthyan microremains from Morocco and Sardinia. Journal of Paleontology 82, 984-995. DOI 10.1666/07-102.1

DruCE, E.C. 1969. Devonian and Carboniferous conodonts from Bonaparte Gulf Basin, Northen Australia. Bureou of Mineral Resources, Geology and Geophysics Bulletin 69, 1-243.

DzIK, J. 1976. Remarks on the evolution of Ordovician conodonts. Acta Palaeontologica Polonica 21, 395-455.

DZIK, J. 1997. Emergence and succession of Carboniferous conodont and ammonoid communities in the Polish part of the Variscan sea. Acta Palaeontologica Polonica 42, 57-164.

EBNER, F. 1980. Conodont localities in the surroundings of Graz/Styria, 101-127. In SchÖNLAUB, H.P. (ed.) Second European Conodont Symposium - ECOS II. Abhandlungen der Geologischen Bundesaltstalt 35.

Flajs, G. \& FeIst, R. 1988. Index conodonts, trilobites and environment of the Devonian-Carboniferous boundary beds at La Serre (Montagne Noire, France). Courier Forschungs-Institut Senckenberg 100, 53-107.

Funedda, A. \& OgGiano, G. 2009. Outline of the Varisican basement of Sardinia. Rendiconti della Società Paleontologica Italiana 3, 23-35.

Girard, C., Cornée, J.-J., Corradini, C., Fravalo, A. \& Feist, R. 2014. Paleoenvironmental changes at Col des Tribes (Montagne Noire, France), a reference section for the Famennian of north Gondwana-related areas. Geological Magazine 151, 864-884. DOI 10.1017/S0016756813000927

Hass, W.H. 1959. Conodonts from the Chappel Limestone of Texas. U.S. Geological Survey Professional Paper 294, 365-399.

Hinde, G.J. 1879. On conodonts from the Chazy and Cincinnati group of the Cambro-Silurian and from the Hamilton and 
Genesee shale divisions of the Devonian in Canada and the United States. Geological Society of London Quarterly Journal 35, 351-369.

DOI 10.1144/GSL.JGS.1879.035.01-04.23

HudDLe, J.H. 1934. Conodonts from New Albany shale of Indiana. Bulletins of American Paleontology 72, 1-136.

JAEGER, H. 1976. Das Silur und Unterdevon vom thuringischen Typ in Sardinien und seine regionalgeologische Bedeutung. Nova Acta Leopoldina 45(224), 263-299.

JI, Q. 1985. Study on the phylogeny, taxonomy, zonation and biofacies of Siphonodella (Conodonta). Bulletin of the Institute of Geology 11, 51-75.

JI, Q. 1987. New results from Devonian-Carboniferous boundary beds in South China. Newsletters on Stratigraphy 17, 155-167.

KAISER, S.I. 2005. Mass extinctions, climatic and-oceanographic changes at the Devonian-Carboniferous boundary. $156 \mathrm{pp}$. Doctoral thesis, Ruhr-University Bochum; http://deposit.ddb.de/cgi-bin/dokserv?idn=976489856.

KaISER, S.I. 2007. Conodontenstratigraphie und Geochemie $\left(\delta^{13} \mathrm{C}_{\text {carb }}, \delta^{13} \mathrm{C}_{\text {org }}, \delta^{18} \mathrm{O}_{\text {phosph }}\right)$ aus dem Devon/Karbon-Grenzbereich der Karnischen Alpen. Jahrbuch der Geologischen Bundesalstalt 147, 301-314.

KaISER, S.I. 2009. The Devonian/Carboniferous stratotype section La Serre (Montagne Noire) revisited. Newsletters on Stratigraphy 43, 195-205.

DOI 10.1127/0078-0421/2009/0043-0195

Kaiser, S.I., Becker, R.T., Spalletta, C. \& Steuber, T. 2009. High-resolution conodont stratigraphy, biofacies and extinctions around the Hangenberg Event in pelagic successions from Austria, Italy and France. Palaeontographica Americana 63, 97-139.

Kaiser, S.I. \& Corradini, C. 2011. The early Siphonodellids (Conodonta, Late Devonian-Early Carboniferous): overview and taxonomic state. Neues Jahrbuch für Geologie und Paläontologie, Abhandlungen 261, 19-35.

DOI 10.1127/0077-7749/2011/0144

Kaiser, S.I., Steuber, T. \& Becker, R.T. 2008. Environmental change during the Late Famennian and Early Tournaisian (Late Devonian-Early Carboniferous) - implications from stable isotopes and conodont biofacies in southern Europe. Geological Journal 43, 241-260. DOI 10.1002/gj.1111

Kalvoda, J., Kumpan, T. \& BÁBeK, O. 2015. Upper Famennian and Lower Tournaisian sections of the Moravian Karst (Moravo-Silesian Zone, Czech Republic): a proposed key area for correlation of the conodont and foraminiferal zonations. Geological Journal 50, 17-38. DOI 10.1002/gj.2523

KoRn, D. 1999. Famennian ammonoid stratigraphy of the Maider and Tafilalt (eastern Anti-Atlas, Morocco). Abhandlungen der Geologischen Bundesanstalt 54, 147-179.

KoRn, D. \& Weyer, D. 2003. High-resolution stratigraphy of the Devonian-Carboniferous transitional beds in the Rhenish Mountains. Mitteilungen aus dem Museum für Naturkunde in Berlin, Geowissenschaftliche Reihe 6, 79-124.

Kumpan, T., BÁbek, O., Kalvoda, J., FrÝda, J. \& Grygar, T.M. 2014. A high-resolution, multiproxy stratigraphic analysis of the Devonian-Carboniferous boundary sections in the Moravian Karst (Czech Republic) and a correlation with the Carnic Alps (Austria). Geological Magazine 151, 201-215.

DOI $10.1017 /$ S0016756812001057
Lovisato, D. 1894. Il Devoniano nel Gerrei (Sardegna). Atti della Reale Accademia dei Lincei, Rendiconti Classe Scienze Fisiche Matematiche Naturali 3, 460-470.

Mossoni, A., Corradini, C. \& Spalletta, C. 2013. Conodonts from the Monte Taccu section (Famennian-Tournaisian, Sardinia, Italy). Asociación Paleontológica Argentina, Publicación Especial 13, 85-90.

Murru, M. 1975. Primi risultati biostratigrafici sul Siluriano-Devoniano del M. Lora (Sardegna sud-orientale). Rendiconti del Seminario della Facoltà di Scienze dell'Università di Cagliari 45, 325-331.

OlivieRI, R. 1965. L'aspetto della fauna a Conodonti del Devoniano superiore del Gerrei (Sardegna). Bollettino della Società Paleontologica Italiana 4, 28-63.

Olivieri, R. 1970. Conodonti e zonatura del Devoniano superiore e riconoscimento del Carbonifero inferiore nei calcari di Corona Mizziu (Gerrei, Sardegna). Bollettino della Società Paleontologica Italiana 8, 63-152.

OlivieRI, R. 1985. Middle and Late Devonian conodonts from Southwestern Sardinia. Bollettino della Società Paleontologica Italiana 23(1984), 269-210.

Paproth, E., Feist, R. \& Flajs, G. 1991. Decision on the Devonian-Carboniferous boundary stratotype. Episodes 14, 331-336.

Perri, M.C. \& Spalletta, C. 1991. Famennian conodonts from Cava Cantoniera and Malpasso sections, Carnic Alps, Italy. Bollettino della Società Paleontologica Italiana 30(1), 47-78.

Pierce, R.W. \& LAgenheim, R.L. JR. 1974. Platform conodonts of the Monte Cristo group, Mississippian, Arrow canyon Range, Clark County, Nevada. Journal of Paleontology 48(1), 149-169.

Pomesano Cherchi, A. 1963. I primi conodonti della Sardegna nei calcari neodevonici del Gerrei. Istituto di Geologia e Paleontologia dell'Università di Cagliari 2, 1-11.

SANDBERG, C.A. \& ZiEgLER, W. 1979. Taxonomy and biofacies of important conodonts of Late Devonian styriacus-Zone, United States and Germany. Geologica et Palaeontologica 13, $173-212$.

SAndBerg, C.A., Ziegler, W., Leuteritz, K. \& Brill, S.M. 1978. Phylogeny, speciation and zonation of Siphonodella (Conodonta, Upper Devonian and Lower Carboniferous). Newsletters on Stratigraphy 7, 102-120.

SchÖNLAUB, H.P. 1969. Conodonten aus dem Oberdevon und Unterkarbon des Kronhofgrabens (Karnischen Alpen, Österreich). Jahrbuch der Geologischen Bundesanstalt 112, 321-354.

Schönlaub, H.-P., Attrep, M., Boeckelmann, K., Dreesen, R., Feist, R., Fenninger, A., Hahn, G., Klein, P., Korn, D., Kratz, R., Magaritz, M., Orth, C.J. \& Schramm, J.M. 1992. The Devonian/Carboniferous boundary in the Carnic Alps (Austria) - A multidisciplinary approach. Jahrbuch der Geologischen Bundesalstalt 135, 57-98.

Schönlaub, H.-P., Feist, R. \& Korn, D. 1988. The DevonianCarboniferous boundary at the section "Grüne Schneid" (Carnic Alps, Austria): A preliminary report. Courier Forschungs-Institut Senckenberg 100, 149-467.

Spalletta, C. \& Vai, G.B. 1982. Contatto Devoniano pelagicoflysch ercinico a Villasalto (Gerrei), 117-118. In CARMIGNANI, 
L., Cocozza, T., Ghezzo, C., Pertusati, P.C. \& Ricci, C.A. (eds) Guida alla Geologia del Paleozoico sardo. Guide Geologiche Regionali - Società Geologica Italiana.

SweEt, W.C. 1988. The Conodonta: morphology, taxonomy, paleoecology, and evolutionary history of a long-extinct animal phylum. Oxford Monographs on Geology and Geophysics $10,1-212$.

Voges, A. 1959. Conodonten aus dem Unterkarbon I and II (Gattendorfiaund Pericyclus-Stufe) des Sauerlandes. Paläontologische Zeitschrift 3, 266-314. DOI 10.1007/BF02987939

WANG, C.Y. \& YIN, B. 1984. Conodont zonations of early Lower Carboniferous and Devonian-Carboniferous boundary in pelagic facies, South China. Acta Palaeontologica Sinica 23, 224-238.

ZIEGLER, W. 1957. Die Gliederung des Oberdevons und Unterkarbons am Steinberg westlich von Graz mit Conodonten, 25-60. In Flugel, H. \& Ziegler, W. Mitteilungen des naturwissenschaftlichen Vereins der Steiermark 87.

ZIEGLER, W. 1960. Conodonten aus dem Rheinischen Unterdevon (Gedinnium) des Remscheider Sattels (Rheinisches Schiefergebirge). Paläontologische Zeitschrift 34, 169-201. DOI 10.1007/BF02987050
ZIEGLER, W. 1962. Taxonomie und Phylogenie Oberdevonischer Conodonten und ihre stratigraphische Bedeutung. Abhandlunghen des Hessisches Landesamt für Bodenforschung 38, $1-166$.

ZIEGLER, W. 1969. Eine neue Conodontenfauna aus dem höchsten Oberdevon. Fortschritte Geologie von Rheinland und Westfalen 17, 179-191.

Ziegler, W. \& Leuteritz, K. 1970. Die Grenze Devon/Karbon, 679-372. In Koch, V.M., LeUTERITZ, K. \& ZiegleR, W. Alter, Fazies und Paläogeographie der Oberdevon/Unterkarbon-Schichtenfolge an der Seiler bei Iserlohn. Fortschritte in der Geologie der Rheinland und Westfalen 17.

Ziegler, W. \& SAndberg, C.A. 1984. Palmatolepis-based revision of upper part of standard Late Devonian conodont zonation, 179-194. In CLARK, D.L. (ed.) Conodont biofacies and provincialism. Geological Society of America Special Paper 196.

Ziegler, W. \& Sandberg, C.A. 1990. The Late Devonian Standard Conodont Zonation. Courier Forschungs-Institut Senckenberg 121, 1-115.

Ziegler, W. \& SANDBERG, C.A. 1996. Reflexions on Frasnian and Famennian Stage boundary decisions as a guide to future deliberations. Newsletters on Stratigraphy 33, 157-180. 